\title{
EDUKASI PENGANEKARAGAMAN MENU 4 BINTANG (4*) MP-ASI HOMEMADE SEBAGAI UPAYA MENINGKATKAN STATUS GIZI BALITA
}

\author{
Merita Eka Rahmuniyati ${ }^{1}$, Tri Mei Khasana ${ }^{2}$ \\ ${ }^{1)}$ Program Studi Kesehatan Masyarakat Program Sarjana, Fakultas Ilmu Kesehatan, Universitas Respati \\ Yogyakarta \\ ${ }^{2)}$ Program Studi Ilmu Gizi Program Sarjana, Fakultas Ilmu Kesehatan, Universitas Respati Yogyakarta \\ e-mail : merita_er@respati.ac.id
}

\begin{abstract}
Abstrak
Praktik Pemberian Makan Bayi dan Anak (PMBA) yang tepat dapat memperbaiki status gizi bayi/anak. Lebih dari $50 \%$ kematian anak balita terkait dengan keadaan kurang gizi, dan dua pertiga diantara kematian tersebut terkait dengan praktik pemberian makan yang kurang tepat pada bayi dan anak (UNICEF, 2013). Pemberian makan yang baik sejak masa awal pemberian MP-ASI hingga usia dua tahun merupakan salah satu upaya mendasar untuk menjamin pencapaian kualitas tumbuh kembang dalam 1000 Hari Pertama Kehidupan. MP-ASI menu 4* sangat dianjurkan untuk memenuhi kebutuhan gizi anak dalam usia golden period. Kegiatan ini dilaksanakan di Dusun Pokoh yang diikuti 15 peserta (ibu kader dan ibu balita). Kegiatan ini terdiri dari penyuluhan, pemutaran video pembuatan MP-ASI serta pembagian buku resep bagi para peserta. Peserta sangat antusias mengikuti kegiatan ini. Sebanyak $73,3 \%$ tingkat pengetahuan peserta mengalami peningkatan setelah mendapatkan edukasi berupa penyuluhan dan sebanyak 33,3\% peserta tidak membuat MP-ASI secara mandiri. Pemutaran video merupakan sarana audio visula yang menarik dalam menyampaikan suatu informasi. Edukasi menu $4 *$ MP-ASI homemade ini dapat meningkatkan pengetahuan ibu balita sehingga ibu balita dapat memberikan secara tepat sesuai umur, waktu pemberian MP-ASI $4^{*}$, serta ibu balita juga dapat menjadi lebih terampil dan mandiri dalam membuat MP-ASI $4 *$ dari bahan pangan lokal yang memiliki nilai gizi yang tinggi, sehingga dapat meningkatkan status gizi balita.
\end{abstract}

Kata Kunci: MP-ASI, 4 Bintang, Homemade

\begin{abstract}
Appropriate Infant and Child Feeding Practices (PMBA) can improve the nutritional status of infants / children. More than 50\% of the deaths of children under five are related to malnutrition, and two thirds of these deaths are related to inappropriate feeding practices for infants and children (UNICEF, 2013). Giving good food since the initial period of complementary feeding until the age of two years is one of the fundamental efforts to ensure the achievement of quality growth and development in the first 1000 days of life. MP-ASI menu $4 *$ is highly recommended to meet the nutritional needs of children in the golden period. This activity was carried out in Pokoh Hamlet and attended by 15 participants (mothers of cadres and mothers of toddlers). This activity consists of counseling, video screening of complementary foods and the distribution of recipe books for the participants. Participants were very enthusiastic about participating in this activity. As many as $73.3 \%$ of the participants' level of knowledge increased after receiving education in the form of counseling and as many as $33.3 \%$ of participants did not make complementary foods independently. Video playback is an attractive audio visual means of conveying information. The education menu for $4 *$ home made MP-ASI can increase the knowledge of the toddler's mother so that the toddler's mother can give exactly according to age, the timing of $4 *$ MP-ASI, and toddlers can also be more skilled and independent in making $4 *$ complementary foods. from local food ingredients that have high nutritional value, so as to improve the nutritional status of toddler
\end{abstract}

Keywords: MP-ASI ; 4 Star ; Homemade 


\section{PENDAHULUAN}

Masalah gizi dapat terjadi dalam siklus kehidupan dimulai sejak dalam kandungan sampai usia lanjut. Saat ini Indonesia menghadapi masalah gizi ganda yang harus mendapatkan perhatian serius dalam penanganannya. Masalah gizi kurang dapat menyebabkan gangguan kesehatan pada siklus kehidupan. Awal kehamilan sampai anak berusia dua tahun merupakan periode kritis terjadinya gangguan pertumbuhan, termasuk perawakan pendek/stunting.

Balita stunting dan kurus masih cukup tinggi di Indonesia, prevalensi balita stunting sebanyak $30,8 \%$ dan balita kurus sebesar $6,7 \%$. Kasus stunting balita di Sleman masih tinggi. Pada tahun 2018 terdapat $11 \%$ balita mengalami stunting, balita gizi kurang 7,32 \%, dan balita kurus 3,97\%, walaupun secara statistik, angka tersebut mengalami penurunan dibandingkan 2017 (Dinas Kesehatan Kabupaten Sleman, 2018).

Praktik Pemberian Makan Bayi dan Anak (PMBA) yang tepat dapat memperbaiki status gizi bayi/anak. Rekomendasi WHO terkait PMBA meliputi Inisiasi Menyusu Dini (IMD), pemberian ASI eksklusif, Makanan Pendamping ASI (MP-ASI), pemberian ASI sampai usia dua tahun. MPASI merupakan makanan atau minuman yang memiliki nilai gizi yang diberikan pada bayi atau anak berumur 6-24 bulan (WHO, 2001). Pemberian makan yang baik sejak masa awal pemberian MP-ASI hingga usia dua tahun merupakan salah satu upaya mendasar untuk menjamin pencapaian kualitas tumbuh kembang dalam 1000 Hari Pertama Kehidupan (HPK). Menurut UNICEF (2013), lebih dari $50 \%$ kematian anak balita terkait dengan keadaan kurang gizi, dan dua pertiga diantara kematian tersebut terkait dengan praktik pemberian makan yang kurang tepat pada bayi dan anak.

Menurut WHO (2001) waktu yang tepat untuk memberikan MP-ASI adalah saat bayi berusia 6 bulan. Makanan yang diberikan pun harus sesuai porsi dan gizi yang dibutuhkan pada usia tersebut. MP-ASI yang diberikan harus memiliki kandungan karbohidrat, protein, lemak, sertavitamin dan mineral yang adekuat. Hal tersebut penting bagi bayi yang sedang mengalami masa pertumbuhan. Selain itu, pengolahan dan penyajian makanan perlu dilakukan secara higienis untuk meminimalkan risiko terkontaminasi bakteri dan kotoran.

Berdasarkan studi pendahuluan yang telah dilakukan, saat ini mitra memiliki kurang lebih 70 balita, beberapa diantaranya masih ada yang mengalami gizi kurang. Upaya terus dilakukan untuk meningkatkan status gizi balita, baik upaya dari dusun, kader posyandu maupun dari puskesmas. Hal inilah yang menjadi pertimbangan diperlukan kegiatan edukasi penganekaragaman menu MPASI 4* homemade untuk meningkatkan status gizi balita.

Persoalan yang dihadapi oleh mitra, yaitu masih terdapat balita gizi kurang. Kemungkinan dikarenakan tingkat pengetahuan ibu/keluarga terkait pemberian menu MP-ASI masing rendah dan perilaku ibu/keluarga dalam memberikan MP-ASI dengan menu $4 *$ homemade pada bayi/anak terutama usia 6-24 bulan menu makanannya masih belum bervariasi.

\section{METODE}

Metode kegiatan yang diberikan dalam kegiatan ini berupa edukasi dalam bentuk penyuluhan dan pemutaran video pembuatan MP-ASI menu $4 *$ homemade. Sasaran kegiatan ini adalah kader posyandu dan Ibu balita. Kegiatan dilaksanakan pada bulan September 2020. Kegiatan ini bertempat di Rumah Bapak Dusun Pokoh, Desa Wedomartani, Kecamatan Ngemplak, Kab Sleman, D.I Yogyakarta. Adapun agenda diterapkan pada kegiatan ini berupa : (1) Penyuluhan tentang MP-ASI. Penyuluhan dilakukan untuk memberikan pemahaman peserta terkait MP-ASI terutama menu 4* homemade. Peserta akan diberikan beberapa pertanyaan yang berkaitan dengan MP-ASI, baik sebelum penyuluhan maupun sesudahnya. Adanya pre dan post test menunjukkan perubahan pengetahuan dan pemahaman peserta terkait MP-ASI menu $4^{*}$ homemade. (2) Pemutaran video pengolahan MP-ASI homemade.Pemutaran video berupa kegiatan mengenai cara pengolahan MP-ASI 4* dengan prinsip pada jenis MP-ASI homemade. Menu MP-ASI yang dimasak adalah menu makanan rumahan yang menggunakan bahan-bahan yang mudah dijumpai dan dipraktikkan langsung oleh para ibu di rumah selanjutnya. Adanya pemutaran video tersebut diharapkan menambah referensi menu/resep lebih banyak pada menu MP-ASI $4 *$ homemade, sehingga menu yang didapatkan lebih banyak dan bervariasi. (3) Pemberian buku resep menu 4* home made kepada peserta. Peserta mendapatkan buku resep $4^{*}$ homemade sebagai panduan pembuatan MP-ASI di rumah. 


\section{HASIL DAN PEMBAHASAN}

Kegiatan PKM ini berjalan dengan lancar dan sukses. Kegiatan ini dilaksanakan hari Rabu, 30 September 2020 di Rumah Bapak Dukuh Pokoh, Wedomartani, Ngemplak, Sleman dengan jumlah peserta sebanyak 15 orang yang terdiri dari ibu kader dan ibu balita. Seluruh peserta aktif dan antusias mengikuti serangkaian agenda kegiatan. Adapun beberapa kegiatan yang dilaksanakan dalam PKM ini adalah :

1. Edukasi

Edukasi yang diberikan dalam bentuk penyuluhan terkait MP-ASI 4* homemade. Penyuluhan dilakukan untuk memberikan pemahaman peserta terkait MP-ASI terutama menu $4^{*}$ home made. Materi penyuluhan yakni PMBA, MP-ASI, menu tunggal dan menu $4^{*}$, cara penyajian MP-ASI, cara pembuatan menu MP-ASI dengan $4^{*}$, dan lain-lain. Peserta diberikan beberapa pertanyaan sebelum penyuluhan (pre-test) dengan cara mengisi kuesioner. Hal yang sama dilakukan setelah penyuluhan (post-test), peserta dibagikan kuesioner untuk diisi.

2. Pemutaran video pengolahan MP-ASI homemade.

Pemutaran video berupa kegiatan mengenai cara pengolahan MP-ASI $4 *$ dengan prinsip pada jenis MP-ASI homemade. Menu MP-ASI yang dimasak adalah menu makanan rumahan yang menggunakan bahan-bahan yang mudah dijumpai dan dipraktikkan langsung oleh para ibu di rumah selanjutnya. Adanya pemutaran video tersebut diharapkan menambah referensi menu/resep lebih banyak pada menu MP-ASI $4 *$ homemade, sehingga menu yang didapatkan lebih banyak dan bervariasi.

3. Pemberian buku resep menu $4^{*}$ home made kepada peserta.

Peserta akan mendapatkan buku resep $4^{*}$ home made sebagai panduan pembuatan MP-ASI di rumah.

Kegiatan PKM dapat terlaksana dengan baik juga didukung dengan sarana/prasarana yang memadai, yakni (1) Tempat rumah Bapak Dukuh yang nyaman dan asri, (2) Media elektronik berupa materi yang disajikan dalam bentuk power point, (3) Alat bantu audio visual berupa LCD, soundsystem, laptop.

Edukasi dalam bentuk penyuluhan terkait MP-ASI $4 *$ homemade. Penyuluhan dilakukan untuk memberikan pemahaman peserta terkait MP-ASI terutama menu $4 *$ homemade. Peserta mengisi kuesioner berupa pertanyaan yang diberikan, baik sebelum maupun sesudah penyuluhan.

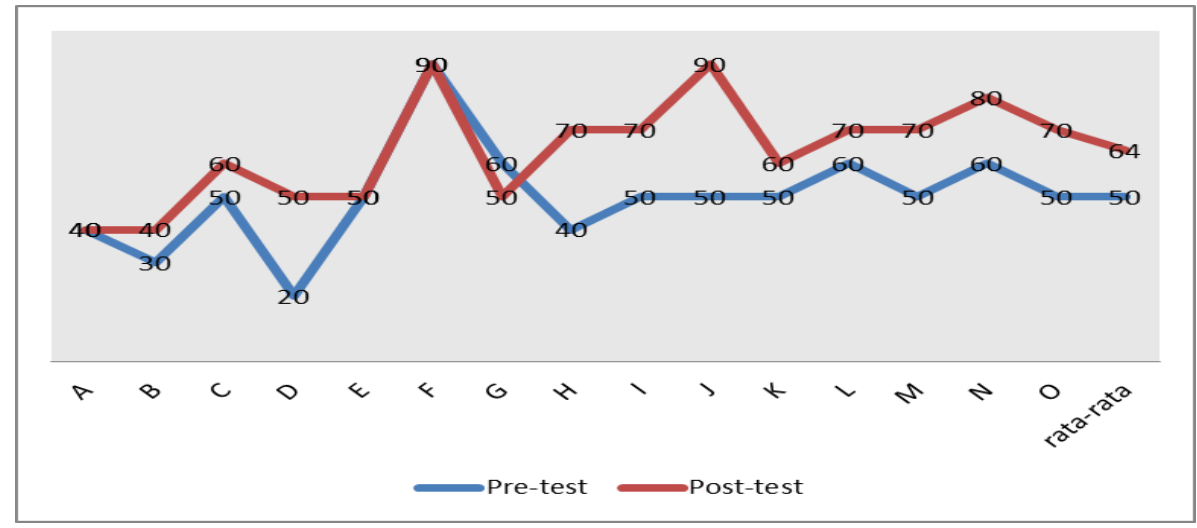

Gambar 3.1 Nilai Pre-Post Pengetahuan Peserta

Gambar 3.1 menunjukkan nilai pre-post masing-masing peserta penyuluhan. Sebelum dilakukan penyuluhan, rata-rata nilai pengetahuan peserta sebesar 50 point, sedangkan setelah diberikan penyuluhan sebesar 64 point. Hal tersebut menunjukkan ada kenaikan sebesar 14 point. Pemberian makan yang baik sejak masa awal pemberian MP-ASI hingga usia dua tahun merupakan salah satu upaya mendasar untuk menjamin pencapaian kualitas tumbuh kembang dalam 1000 Hari Pertama Kehidupan. Kebutuhan energi dan nutrisi anak hingga usia 6 bulan dapat tercukupi oleh pemberian air susu ibu (ASI) saja. Pemberian MP-ASI dapat diberikan karena pemberian ASI saja tidak cukup untuk memenuhi kebutuhan bayi sekitar mulai usia sekitar 6 bulan (IDAI, 2018). Tujuan pemberian MP-ASI pada bayi/anak, yakni : (1) pemenuhan kebutuhan gizi 
bayi/anak, (2) memperkenalkan pola makan keluarga pada bayi/anak, (3) mengembangkan kemampuan bayi untuk menerima bermacam-macam makanan dengan berbagai rasa dan bentuk (kemampuan menelan dan mengunyah), (4) mencoba beradaptasi terhadap makanan yang mengandung energi tinggi.

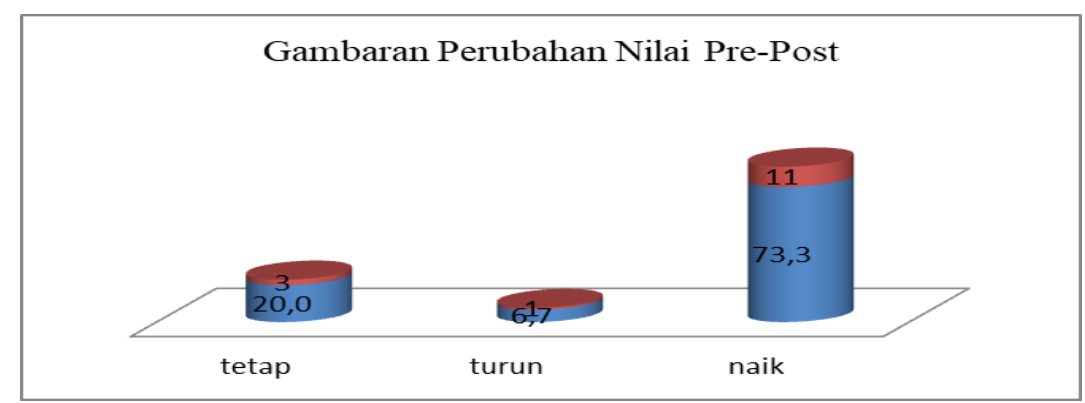

Gambar 3.2 Gambaran Perubahan Nilai Pre-Post Pengetahuan Peserta

Gambar 3.2 menunjukkan adanya perubahan nilai pre-post peserta. Sebanyak 73,3\% peserta mengalami kenaikan nilai setelah dilakukan penyuluhan. Selain itu, juga ada yang memiliki nilai tetap sebesar $20 \%$, dan yang mengalami penurunan point sebesar $6,7 \%$. Pengabdian ini difokuskan pada kegiatan tahap pengenalan MP-ASI menu $4 *$ kepada peserta. Pada tahapan ini dilakukan pengenalan MP-ASI melalui kegiatan edukasi berupa penyuluhan dan cara pembuatan menu $4 *$ melalui pemutaran video. Peserta dari kegiatan ini sebanyak 15 orang yang terdiri dari ibu kader dan ibu yang memiliki balita. Kegiatan ini dilaksanakan kurang lebih 60 menit di Rumah Bapak Dukuh Pokoh. Dikarenakan pelaksanaan kegiatan di era pandemi, sehingga harus ada pembatasan jumlah peserta untuk menghindari kerumunan dan waktu kegiatan yang tidak terlalu lama.

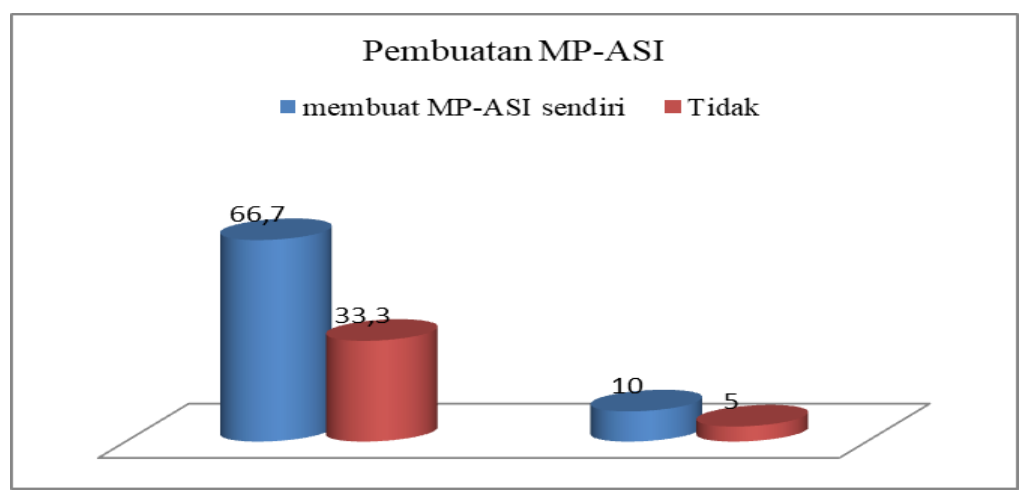

Gambar 3.3 Gambaran Peserta dalam Pembuatan MP-ASI

Gambar 3.3 menunjukkan gambaran pembuatan MP-ASI. Sebanyak 33,7\% peserta tidak membuat MP-ASI sendiri, sedangkan 66,7\% peserta membuat MP-ASI sendiri. Pengabdian kepada Masyarakat ini terkait dengan upaya edukasi kepada masyarakat dalam bentuk penyuluhan terkait MP-ASI 4* homemade. Berdasarkan Notoadmojo (2012), metode dalam pendidikan kesehatan seperti ceramah ini baik digunakan untuk sasaran yang berpendidikan tinggi maupun rendah. Ceramah dapat berhasil apabila pemateri itu menguasai materi yang akan disampaikan dan sasaran. Berdasarkan hasil pre-post menunjukkan hasil bahwa sebanyak $73,3 \%$ ibu balita mengalami peningkatan pengetahuan setelah diberikan penyuluhan. Pengetahuan peserta mengalami peningkatan sesuai dengan riset dari Saputri, dkk yang menunjukkan penerapan penyuluhan tentang MP-ASI meningkatkan praktik pemberian MP-ASI 4 bintang pada bayi umur $6-12$ bulan (Saputri \& Kusumastuti, 2019). Begitu juga dengan penelitian dari Muniarti yang menunjukkan adanya hubungan antara pengetahuan dan sikap ibu tentang pemberian MP-ASI dengan status gizi anak (Muniarti, 2010).

WHO menyarankan agar menu MP-ASI pada 14 hari pertama adalah menu tunggal, selanjutnya menu $4 *$. Pemberian menu MP-ASI $4 *$ bertujuan untuk mencegah anak kekurangan 
zat gizi, baik makro maupun mikro. Menu 4* merupakan menu makanan yang mengandung empat unsur zat gizi, mulai dari karbohidrat, protein hewani, protein nabati, dan sayuran. Karbohidrat bisa berasal dari beras putih, beras merah, kentang, maupun umbi-umbian. Sumber protein hewani bisa didapatkan dari ikan, daging sapi, ceker, hati ayam, daging ayam, telur. Kemudian, sumber protein nabati seperti tahu, tempe, kacang merah, kacang kedelai atau kacang polong. Sumber sayuran berupa labu siam, wortel, bayam, tomat. Selain itu, kebutuhan lemak sehat bisa diperoleh dari kaldu buatan sendiri, unsalted butter, minyak zaitun.

Gambar 3.3 menunjukkan sebanyak $66,7 \%$ peserta membuat MP-ASI $4 *$ secara mandiri. Peserta membuat MP-ASI home made dengan bahan lokal ini karena sudah mendapatkan informasi lebih awal dan pengalaman dari anak-anak sebelumnya. Berdasarkan penelitian yang dilakukan Windayanti, et all (2019) menunjukkan bahwa hasil praktik menunjukkan ibu ada peningkatan pengetahuan tentang MP-ASI dan keterampilan dalam pembuatan tekstur MPASI sesuai kategori usia anak/bayi.

Pemberian MP-ASI lokal memiliki beberapa dampak positif. Beberapa manfaat utama dari Pengolahan MP-ASI lokal yakni (1) ibu lebih memahami dan lebih terampil dalam membuat MPASI dari bahan pangan lokal sesuai dengan kebiasaan dan sosial budaya setempat, sehingga ibu dapat melanjutkan pemberian MP-ASI lokal secara mandiri, (2) meningkatkan partisipasi dan pemberdayaan masyarakat serta memperkuat kelembagaan seperti PKK dan Posyandu, (3) memiliki potensi meningkatkan pendapatan masyarakat melalui penjualan hasil pertanian, (4) sebagai sarana dalam pendidikan atau penyuluhan gizi (Depkes RI, 2006).

Hasil pengabdian menunjukkan sebanyak $33,7 \%$ peserta tidak membuat MP-ASI sendiri. Peserta yang tidak membuat MP-ASI sendiri dikarenakan ribet, waktu pembuatannya lama, tidak cocok untuk anak pertama bahkan ada yang membeli. Diperlukan upaya lebih giat terutama dari tenaga kader posyandu terampil sangat besar terhadap keberhasilan Pemberian makan bayi dan Anak (PMBA), peningkatan pemberdayaan ibu, peningkatan dukungan anggota keluarga serta peningkatan kualitas makanan bayi dan anak yang akan meningkatkan status gizi balita (Widaryanti \& Rahmuniyati, 2019a).

Kegiatan berikutnya adalah pengenalan cara pembuatan menu $4^{*}$ melalui pemutaran video. Video pembuatan MP-ASI 4* ini kami sadur dari UNICEF. Pengabdian ini sesuai dengan hasil penelitian media audio-visual merupakan media yang memliki peranan peningkatan pengetahuan ibu tentang MP-ASI (Wicaksono, 2016). Peserta sangat antusias serta ada beberapa pertanyaan yang diajukan peserta terkait dengan pembuatan MP-ASI $4 *$ tersebut terutama home made.

Upaya lain untuk meningkatkan status gizi bayi/balita yakni dengan penganekaragaman menu 4* yang disajikan dalam bentuk resep. Resep dibuat dari modifikasi dari resep MP-ASI Depkes (2006) dan beberapa referensi menu $4 *$. Widaryanti \& Rahmuniyati (2019b) menunjukkan bahwa menu ini dapat dibagi sesuai umur anak ( $6-9$ bulan, $9-12$ bulan, >12 bulan). Pemberian MP_ASI ini harus sesuai dengan umur dan frekuensi pemberian. Depkes RI (2006) menyatakan untuk tumbuh kembang optimal, anak membutuhkan asupan gizi yang cukup. Bagi bayi usia 0-6 bulan, pemberian ASI saja sudah cukup, namun bagi bayi diatas 6 bulan diperlukan makanan selain ASI yaitu berupa MP-ASI. MP-ASI harus mengandung zat gizi sesuai kebutuhan. Untuk itu, diperlukan pengetahuan dan keterampilan ibu untuk menyediakan MP-ASI yang tepat dan bermutu sesuai dengan kemampuan dan ketesediaan bahan makanan setempat. Oleh karena itu, diperlukan resep - resep MP-ASI sebagai acuan bagi ibu.

\section{SIMPULAN}

Simpulan dari kegiatan ini yaitu peserta sangat antusias mengikuti kegiatan sampai dengan selesai. Sebanyak $73,3 \%$ peserta mengalami peningkatan pengetahuan setelah dilaksanakan penyuluhan. Pemutaran video pembuatan MP-ASI merupakan audio visual yang menarik dalam menyampaikan sebuah informasi.

\section{SARAN}

1. Diperlukan kegiatan pelatihan pembuatan MP-ASI untuk ibu balita terutama untuk MP-ASI menu 4* homemade

2. Peran kader sudah sangat baik, namun diperlukan upaya lebih maksimal dalam mendampingi ibu balita terutama dalam pembuatan MP-ASI menu $4 *$ 


\section{UCAPAN TERIMA KASIH}

Penulis mengucapkan terima kasih kepada Universitas Respati Yogyakarta atas dukungan terhadap kegiatan pengabdian ini.

\section{DAFTAR PUSTAKA}

Depkes RI. (2006). Pedoman Umum Pemberian Makanan Pendamping Air Susu Ibu (MP-ASI) Lokal Tahun 2006.

Dinas Kesehatan Kabupaten Sleman. (2018). Profil Kesehatan Kabupaten Sleman Tahun 2018. Sleman.

IDAI. (2018). Pemberian Makanan Pendamping Air Susu Ibu (MPASI). UKK Nutrisi Dan Penyakit Metabolik IDAI.

Muniarti. (2010). Hubungan Pengetahuan Dan SIkap Ibu Tentang Pemberian MP-ASI Dengan Status Gizi Anak (6-24 bulan) Di Kenagarian Bungo Tanjung Tahun 2009. Jurnal Kesehatan Masyarakat Andalas, 4(2), 88-96. https://doi.org/10.24893/JKMA.V4I2.74

Saputri, F., \& Kusumastuti. (2019). Penerapan Penyuluhan tentang MP ASI terhadap Praktek Pemberian MP ASI 4 Bintang pada Bayi Umur 6-12 Bulan di BPM Jemanis Kabupaten Kebumen. University Research Colloqium, 556-564.

UNICEF. (2013). Unicef Anual Report 2013. Retrieved from https://www.unicef.org/publications/index_73682.html

WHO. (2001). Guiding Principles for Complementary Feeding of The Breastfed Child. Retrieved from https://www.who.int/nutrition/publications/guiding_principles_compfeeding_breastfed.pdf

Wicaksono, D. (2016). Pengaruh Media Audio-Visual Mp-Asi Terhadap Pengetahuan, Sikap Dan Perilaku Ibu Baduta Di Puskesmas Kelurahan Johar Baru. ETHOS (Jurnal Penelitian Dan Pengabdian), 291. https://doi.org/10.29313/ethos.v0i0.1974

Widaryanti, R., \& Rahmuniyati, M. E. (2019a). Evaluasi Pasca Pelatihan Pemberian Makan Bayi dan Anak ( PMBA ) pada Kader Posyandu Terhadap Peningkatan Status Gizi Bayi dan Balita, 4(2), 163-174. https://doi.org/https://doi.org/10.35842/formil.v4i2.273

Widaryanti, R., \& Rahmuniyati, M. E. (2019b). Panduan Pemberian Makanan Bayi dan Anak bagi Kader Dilengkapi Menu 4* untuk Kondisi Normal dan Bencana (1th ed.). Yogyakarta: Respati Press.

Windayanti, H., Masruroh, \& Cahyaningrum. (2019). Pemberian Informasi Tentang Pemberian Makan Bayi dan Anak Usia 0 - 24 Bulan. Indonesia Journal of Community Empowerment (IJCE), 1(2), 23-28. Retrieved from http://jurnal.unw.ac.id:1254/index.php/IJCE/article/view/321 